\title{
The Effect of Information Technology on Quality Management and Employee Performance of the Jember University Library
}

\author{
Achmad Taufik $\mathbf{H}^{1}$, Purnamie Titisari ${ }^{2}$, Sudaryanto ${ }^{3}$ \\ ${ }^{1}$ Central Library, University of Jember \\ ${ }^{2}$ Faculty of Economics and Business, University of Jember \\ ${ }^{3}$ Faculty of Economics and Business, University of Jember
}

\begin{abstract}
One of the factors in question is human resources (HR). The quality and advantages issued by each individual (HR) are expected to contribute to the progress of the organization. Contributions to the progress of the organization in accordance with the opinion of Titisari, Purnamie et al. (2016) "an organization that is always developing is everyone's hope. Both the government and the private sector expect their organizations to grow and develop well. This development is expected to enable organizations to compete, which cannot accelerate with the progress of this organization to be left behind". This study focuses on developing information technology on employee performance, developing quality management on employee performance and developing information technology on quality management. The Jember University Library which will be used as an object in this study has long implemented a quality management system and implementation of information technology in all processes carried out. The object of the research was conducted in the Library with a sample of 46 employees. The data source used is a questionnaire which is primary data and secondary data such as the list of employees and the organizational structure of the University Library of Jember. Varies using a Likert scale. The analytical tool used uses SmartPLS 3.0. In this study obtained results produced by Quality Management $\left(\mathrm{X}_{2}\right)$ on Employee Performance $\left(\mathrm{Y}_{1}\right)$ has a path coefficient value of 0.419 and its effect is significant $(\mathrm{t}=2.897, \mathrm{p}$ $=0.004)$ because $\mathrm{t}>1.96 ; \mathrm{p}<0.005$. The Effect of Information Technology $\left(\mathrm{X}_{1}\right)$ on Employee Performance $\left(\mathrm{Y}_{1}\right)$ has a path coefficient value of 0.456 and its effect is significant $(t=3.188, p=0.002)$ because $t>$ 1.96; $\mathrm{p}<0.005$. The Influence of Information Technology $\left(\mathrm{X}_{1}\right)$ on Quality Management $\left(\mathrm{X}_{2}\right)$ has a path coefficient value of 0.853 and its effect is significant $(t=21.597, p=0,000)$ because $t>1.96 ; p<0.005$. Thus it can be concluded that $\mathrm{Ha}$ is accepted because of t-statistics $>1.96$. Approved with the value of probability it can be concluded that $\mathrm{Ha}$ is accepted because $\mathrm{p}<0.05$.
\end{abstract}

Keywords—human resources; quality management; employee performance; information technology; Partial Least Square (PLS)

\section{Introduction}

One of the factors in question is human resources (HR). The quality and advantages issued by each individual (HR) are expected to contribute to the progress of the organization. Contributions to the progress of the organization in accordance, an organization that is always developing is everyone's hope. Both the government and the private sector expect their organizations to grow and develop well. This development is expected to enable organizations to compete, which cannot accelerate with the progress of this organization to be left behind [1].
The award received by the Jember University Library as a form of recognition of the two institutions, namely with the issuance of ISO 9001:2008 certificates by certification bodies and Library Accreditation by the National Library, prove that the Jember University Library has implemented good quality management standards, but this is often not the same as what happened. The presence and absence of work that is often not in accordance with the schedule becomes something that needs to be addressed. The consistency of employee services is also a note related to quality management that service hours are often not in accordance with the scheduled ones so that this spurred the user in this 
case students questioned and protested even thought there were not too many. The use of an identity (Name Tag) as an officer identifier to the user also has been gradually abandoned. From this phenomenon, the researcher was interested in analyzing the application of quality management at the Jember University Library. A review of the application of quality management especially ISO 9001 is in accordance with the opinion of Tjiptono and Diana (2003:88) which state that ISO 9001 is the most comprehensive standard and is used to guarantee quality at the design and development, production, installation and service.

Luburic (2015)[2], said that the quality management principle consists of eight elements namely 1.Customer Focus 2. Leadership 3. Involvement of People 4. Process Approach 5. System Approach to Management 6. Continual Improvement 7. Factual Approach to Decision Making 8. Mutually Beneficial Supplier Relationships. Related to the relevance of the research conducted, the limitations of knowledge, experience and time of research, researchers limit the problems of research tha is focused on ISO 9001:2008 quality management with five principles, namely leadership, involvement of all employees, process approach, management systems approach and continuous improvement with the object of research in the Jember University Library.

The technology applied in the Jember University Library continues to increase so that the ability to use the technology requires motivation, knowledge and commitment from the leadership and employees of the Jember University Library so that the main goal of serving users in finding and obtaining information can be fulfilled. Prabowo (2009)[3] states that ISO 9001: 2008 is a system that is part of Integrated Quality Management (total quality management). Whereas the user in this case the student expects that the use of information technology is simple as expressed by Sudaryanto (2011)[4] that the level of education has a close relationship with ICT-Computer adoption. The higher the level of education, they prefer to use more sophisticated ones such as Personal Data Assistance (PDA) or cellphones that are more stylist than computers or PCs. This spurred the Library to improve services better by upgrading information technology according to the needs of users.

Various results of research on the influence of technology on performance indicate a research gap. Research conducted by Jumaili (2005)[5] found results that a. Relationship to new information system technology will improve individual performance in the company/organization shows a positive and significant influence Another study conducted by Nugroho (2016)[6] found results namely that information technology has a positive and significant effect on employee performance. Different results are shown by Tsani (2017)[7] that the variable use of information technology does not significantly influence the employee performance of the Surakarta Branch of Bank Rakyat Indonesia Syariah.

\section{Literature review}

Definition of performance is recording the results achieved in carrying out special functions of a work or activity working for a certain period indicated by the process or way of working and the results achieved. Whereas Byars and Rue (2000)[10] defines performance as the degree of completion of tasks that accompany one's work. According to Bernardin (2006) and Russell (1993)[11] there are six criteria for assessing employee performance, namely:

1) Quality is the degree to which the process or adjustment is in the ideal way of doing activities or fulfilling activities that are as expected. The process or result is close to the ideal to fulfill the purpose and purpose.

2) Quantity is related to the unit of quantity or amount produced realized through the currency value, number of units, or the number of cycles of activities that have been completed.

3) Time (timeliness) is the level at which activities have been completed with a faster time than specified and maximizing the time available for other activities or the time needed to complete the activities and products produced.

4) Cost effectiveness is the level where the use of company resources in the form of human, financial, and technology is maximized to get the highest yield or reduction in losses from each unit.

5) Monitoring needs (need for supervision) is the level at which an employee can do his job without the need to ask for help or guidance from his supervisor or related to the individual's ability to complete work without intervention and assistance from the leader.

6) Interpersonal impact (interpersonal impact) is the level at which an employee feels confident, has good wishes and works together among coworkers.

Information technology produces an information system, therefore employees play an important role 
in the operation of information technology directly or indirectly. According to Suwanto (2006)[9], information technology applications that are covered in the scope of an information system, both in the library and in documentation and information centers in general can be classified in 4 main areas, namely:

1.Library Housekeeping

2. Information Retrieval

3. General Purpose Software

4. Library Networking

\section{Research Hypothesis}

1. Effect of Information Technology on Employee Performance at Uember University Library Unit (H1) Information technology applied in an institution / institution in this case the library will greatly support work and affect the performance of its employees.

Jumaili (2015) shows that the relationship of new information system technology will improve individual performance in the company / organization to have a positive and significant influence.

Nugroho (2016)[6] shows the results that information technology has a positive and significant effect on employee performance. Arisuniarti (2016)[13] shows the results that there is a positive influence between information technology and performance at Warmadewa University can be accepted, other results show that integrated information systems have a positive and significant influence on the performance of Warmadewa University employees. Based on some of these studies, it can be formulated for the first hypothesis (H1):

H1: Information Technology influences Employee Performance

2. Effect of Quality Management on Employee Performance UPT Jember University Library (H2) Quality management (implementation of ISO 9001: 2008 and accreditation) is an evaluation of the system of work carried out in an organization. Good quality lies in the supporting components, one of these components is the performance of employees in an organization.

Semuel (2011)[12] shows the results that the implementation of ISO 9001 QMS is able to significantly improve employee performance through the company's quality culture as its mediation. Based on the description of the research above, the second hypothesis $(\mathrm{H} 2)$ is:
H2: Quality Management influences employee performance

3. Effect of Information Technology on Quality Management UPT Jember University Library (H3)

Information technology used in the Library UPT has an influence on employee performance in performing services to users. Employee

performance in serving users is included in the accreditation element.

Wai, Seebaluck and Teeroovengadum (2011)[14], state that the organization's ability to successfully use IT in supporting quality management depends largely not only on IT resources but also on its ability to utilize IT. Based on the description of the research above, the third hypothesis (H3) is:

H3: Information Technology influences Quality Management

\section{Objectives}

Based on the research problem formulation, the purpose of this study is to find out how the effects of each variable are:

a) Test the influence of information technology on the performance of employees in the Jember University Library

b) Test the influence of information technology on quality management at the Jember University Library

c) Test the influence of quality management on employee performance in the Jember University Library

\section{Research methodology}

\section{Research and Definition of Operational Variables}

Operational definitions of variables in this study are intended to get the same understanding of the variables examined by researchers, the explanation of the operational definitions of the variables in question is as follows:

a) Information Technology $\left(\mathrm{X}_{1}\right)$ is a study, design, development, implementation, support or management of computer-based information systems, especially software applications and computer hardware, information technology that is covered in the scope of an information system, classified in 4 main fields (Suwanto, 2006)[9], namely:

1) Library Housekeeping is a routine activity that needs to be done so that the library runs as it should, consisting of: 
a) Integrated library system

b) Systems that are integrated with other institutions

c) Employees have access to using information technology

d) Information technology has an influence on employees

e) Information technology can complete employee tasks

2) Information Retrieval is tracking information using electronic means namely OPAC (Online Public Access Catalog), CD-ROM that can provide information in accordance with existing collections.

3) General Purpose Software is software that can be used for documentation and information purposes, including:

a) Use of computer applications in making reports or other tasks

b) An easy-to-use information system device

4) Library Networking is collaboration with other institutions and libraries in meeting information needs of users.

b) Quality Management $\left(\mathrm{X}_{2}\right)$ is a philosophy and organizational culture that emphasizes efforts to create constant quality through every aspect of organizational activities. Five principles in ISO 9001: 2008, namely:

1) Leadership (leadership) is an effort to influence behavior and motivate employees to be able to work together and work productively for company goals, including:
a) Clear organizational vision
b) Setting targets or targets in each activity
c) Trust in coworkers
d) Training for employees

2) Employee involvement (involvement of people) is the degree to which people are known from their jobs, actively participate in them and assume their achievements are important for self-esteem, including:
a) The importance of contributions to work
b) Performance assessment
c) Active in increasing competence, knowledge and experience
d) Sharing knowledge
e) Discuss issues with coworkers

3) Process approach (process approach) is intended to achieve optimal results and can be achieved more efficiently, including:
a) Each division in the organization is interrelated in the process of work activities
b) Organizations give assignments to work clearly
c) Responsibility for work
d) The organization evaluates the work of each division
e) Dependence between lines in work
f) The organization evaluates the system

4) The system approach to management (system approach to management) is intended to produce a clear and easy work structure for employees to implement, including:
a) Organizations have a good system to achieve goals
b) Dependence between lines in work
c) Evaluation to improve the system

5) Continual improvement is intended to have a positive impact on the organization, including:
a) Provide training for improvement
b) Provide training without waiting for problems to arise
c) Improvement of positive actions

c. Employee Performance $\left(\mathrm{Y}_{1}\right)$ is the work result in the quality and quantity achieved by an employee in carrying out his duties. Six criteria for assessing employee performance, namely:

1) Quality, ie employees are able to complete work assignments given consistently

2) Quantity is the amount generated through the cycle of activities that have been completed.

3) Timeliness is an activity that has been completed more efficiently.

4) Need for supervision, ie employees are able to make alternative solutions at each time

\section{Results and discussions}

Hypothesis testing is done by looking at the probability results, namely the p-value $<0.05$ with alpha $5 \%$, the t-table value is 1.96 with alpha $5 \%$, so the criteria for accepting/rejecting the hypothesis are $\mathrm{Ha}$ accepted and $\mathrm{H} 0$ rejected when t-statistics $>1.96$ or t-statistics> t-table. Criteria for accepting/rejecting hypotheses using probability then $\mathrm{Ha}$ is accepted if $\mathrm{p}<0.05$

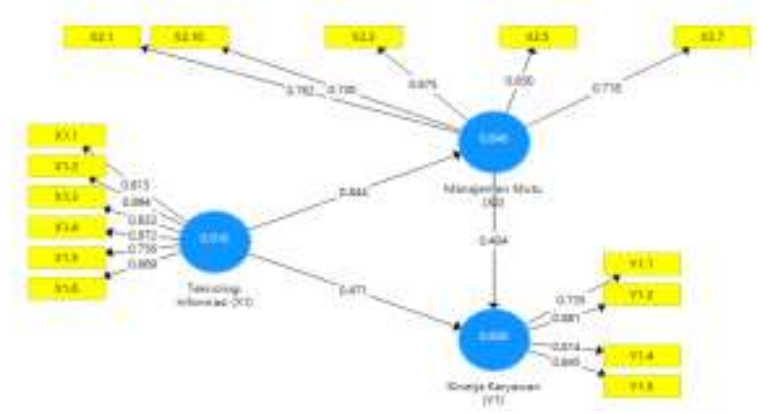

Fig.1 Result Loading Factor 


\begin{tabular}{|c|c|c|c|c|c|}
\hline & $\begin{array}{l}\text { nal } \\
\text { Samp } \\
\text { le }(O)\end{array}$ & $\begin{array}{l}\text { ple } \\
\text { Mea } \\
\mathrm{n} \\
(\mathrm{M})\end{array}$ & $\begin{array}{l}\text { ard } \\
\text { Devia } \\
\text { tion } \\
\text { (STD } \\
\text { EV) }\end{array}$ & $\begin{array}{l}\text { Statisti } \\
\text { cs } \\
(\mid \mathrm{O} / \mathrm{ST} \\
\mathrm{DEV} \mid)\end{array}$ & $\begin{array}{l}\text { Valu } \\
\text { es }\end{array}$ \\
\hline $\begin{array}{l}\text { Manajeme } \\
\mathrm{n} \quad \text { Mutu } \\
\left(\mathrm{X}_{2}\right)^{->} \quad- \\
\text { Kinerja } \\
\text { Karyawan } \\
\left(\mathrm{Y}_{1}\right)\end{array}$ & 0.404 & 0.419 & 0.125 & 2.897 & $\begin{array}{c}0.00 \\
4\end{array}$ \\
\hline $\begin{array}{l}\text { Teknologi } \\
\text { Informasi } \\
\left(\mathrm{X}_{1}\right)^{\prime}-> \\
\text { Kinerja } \\
\text { Karyawan } \\
\left(\mathrm{Y}_{1}\right)\end{array}$ & 0.471 & 0.456 & 0.136 & 3.188 & $\begin{array}{c}0.00 \\
2\end{array}$ \\
\hline $\begin{array}{l}\text { Teknologi } \\
\text { Informasi } \\
\left(\mathrm{X}_{1}\right)^{->} \\
\text {Manajeme } \\
\mathrm{n} \quad \text { Mutu } \\
\left(\mathrm{X}_{2}\right)\end{array}$ & 0.844 & 0.853 & 0.038 & 21.597 & $\begin{array}{c}0.00 \\
0\end{array}$ \\
\hline
\end{tabular}

Table 1. Path Coeficients

The results of the analysis carried out using the SmartPLS application can be explained as follows:

1.Effect of Information Technology on Quality Management ISO 9001: 2008

The results of the research conducted show the effect of Information Technology on Quality Management ISO 9001: 2008 with the influence of each indicator on the construct (figure 1) which can be explained that:

a. Information Technology $\left(\mathrm{X}_{1}\right)$ with the housekeeping library (Information System Integration) construct $\left(\mathrm{X}_{1.1}\right)$ loading factor 0.813 and $\left(\mathrm{X}_{1.2}\right)$ loading factor 0.894 has an influence on Quality Management $\left(\mathrm{X}_{2}\right)$ indicating that Information System Integration (Library Automation) with support the complete module influences the quality management process that has been achieved by the Library, especially influencing the work activity process. From the two Information Technology indicators $\left(\mathrm{X}_{1}\right)$ the highest loading factor value, namely $\left(\mathrm{X}_{1.2}\right)$ shows that an integrated system increases the productivity and creativity of employees in completing assigned tasks so as to influence management performance in this case the quality management construct $\left(\mathrm{X}_{2}\right)$ leadership (leadership) $\left(\mathrm{X}_{2.1}\right)$ to be able to set targets or targets and can take policies effectively and efficiently.

b. Information Technology $\left(X_{1}\right)$ with the construct of Information Retrieval $\left(\mathrm{X}_{1.3}\right)$ loading factor 0.833 and $\left(\mathrm{X}_{1.4}\right)$ loading factor 0.872 has an influence on Quality Management $\left(\mathrm{X}_{2}\right)$ indicating that tracking information with a system already in The library is in accordance with the expectations of the user in finding valid and accurate information and the use of existing modules can be learned and is easy to use. From the two constructs of Information Technology $\left(\mathrm{X}_{1}\right)$ the highest loading factor value, namely $\left(\mathrm{X}_{1.4}\right)$ shows that the modules contained in information retrieval applications, procedures for using applications in finding valid and accurate information are easy to learn.

c. Information Technology (X1) with the construct of General Purpose Software $\left(\mathrm{X}_{1.5}\right)$ loading factor 0.756 and $\left(\mathrm{X}_{1.6}\right)$ loading factor 0.869 has an influence on Quality Management $\left(\mathrm{X}_{2}\right)$ indicating that the use of software applications used in forms of commercial software and software created for their own needs can support work activities and can be studied and in accordance with the work done. From the two constructs the biggest loading factor value is $\left(\mathrm{X}_{1.6}\right)$ indicating that the software made for own needs is easy to use and the module is in accordance with what is needed to support work activities and supports quality management $\left(\mathrm{X}_{2}\right)$ with constructs $\left(\mathrm{X}_{2.7}\right)$ which shows the library has a good system structure to reach the target.

The results of the study concluded that Information Technology had a significant effect on Quality Management of 21,597, meaning that the technology used and being developed in the Library had an impact on Quality Management (ISO 90001: 2008) in the Jember University Library. This needs to be maintained so that the quality achieved through ISO 9001: 2008 in the library is maintained.

2. Effect of Information Technology on Employee Performance

The results of the research conducted indicate that the influence of Information Technology on Employee Performance with the influence of each construct (Figure 1) can be explained that:

a. Information Technology $\left(\mathrm{X}_{1}\right)$ with an indicator of the housekeeping library (Information System Integration) $\left(\mathrm{X}_{1.1}\right)$ loading factor 0.813 and $\left(\mathrm{X}_{1.2}\right)$ loading factor 0.894 has 
an influence on Employee Performance $\left(\mathrm{Y}_{1}\right)$ indicating that Information System Integration (Library Automation) with support Complete modules affect the performance of management and employees to carry out work activities, so that the integrated system makes it easier for employees to complete their tasks. From the two constructs of Information Technology $\left(X_{1}\right)$ the highest loading factor value $\left(\mathrm{X}_{1.2}\right)$ shows that an integrated system helps increase employee productivity and creativity in completing assigned tasks.

b. Information Technology $\left(\mathrm{X}_{1}\right)$ with Information Retrieval $\left(\mathrm{X}_{1.3}\right)$ loading factor 0.833 and $\left(\mathrm{X}_{1.4}\right)$ loading factor 0.872 has an influence on Employee Performance $\left(\mathrm{Y}_{1}\right)$ indicating that tracking information with systems in the Library is appropriate with the hope of employees in finding valid and accurate information and the use of existing modules can be learned and easy to use. From the two constructs of Information Technology $\left(\mathrm{X}_{1}\right)$ the highest loading factor value, namely $\left(\mathrm{X}_{1.4}\right)$ shows that the modules contained in information retrieval applications, application usage procedures in finding information in order to obtain valid and accurate data are easy for employees to learn.

c. Information Technology $\left(\mathrm{X}_{1}\right)$ with indicators of General Purpose Software $\left(\mathrm{X}_{1.5}\right)$ loading factor 0.756 and $\left(\mathrm{X}_{1.6}\right)$ loading factor 0.869 has an influence on Employee Performance $\left(\mathrm{Y}_{1}\right)$ indicating that the use of software applications used in forms of commercial software and software created for their own needs can support work activities and can be learned by employees and in accordance with the work required. Of the two constructs the biggest loading factor value is $\left(\mathrm{X}_{1.6}\right)$ indicating that software created for own needs is easy to use and the module is in accordance with what is needed to support employee work activities.

The results of the study concluded that Information Technology had a significant effect on employee performance at 3.188 , meaning that the technological developments implemented in the library had an impact on the performance of the University of Jember library employees. Efforts to improve employee quality related to information technology need to be improved. The findings are in accordance with the research conducted by Nugroho (2016)[6].

3. Effect of ISO 9001: 2008 Quality Management on Employee Performance
The results of the research conducted show that the effect of Quality Management $\left(\mathrm{X}_{2}\right)$ on Employee Performance $\left(\mathrm{Y}_{1}\right)$ with the influence of each indicator (Figure 1) can be explained that:

a. Quality Management $\left(\mathrm{X}_{1}\right)$ with Leadership (Leadership) indicators $\left(\mathrm{X}_{2.1}\right)$ with 0.762 loading factor has an effect on quality management. This opinion is reinforced by the results of previous research conducted by Rahman (2016)[8] which states that the application of ISO 9001: 2008 QMS in the form of leadership has a positive and significant effect on the performance of employees of PT PJB UP Muara Karang.

b. Quality Management $\left(\mathrm{X}_{2}\right)$ with the Employee Management indicator $\left(\mathrm{X}_{2.3}\right)$ with a loading factor of 0.875 influencing quality management. This opinion is reinforced by the results of previous research conducted by Rahman (2016)[8] which states that the application of ISO 9001: 2008 QMS in the form of involvement of all employees has a positive and significant effect on the performance of employees of PT PJB UP Muara Karang.

c. Quality Management $\left(\mathrm{X}_{2}\right)$ with Process Management indicators $\left(\mathrm{X}_{2.5}\right)$ with a loading factor of 0.850 influencing quality management. This opinion is reinforced by the results of previous research conducted by Rahman (2016)[8] which states that the implementation of ISO 9001: 2008 QMS in the form of a process approach has a positive and significant effect on the performance of employees of PT PJB UP Muara Karang.

d. Quality Management $\left(\mathrm{X}_{2}\right)$ with Supplier Management indicators (System Approach to Management) $\left(\mathrm{X}_{2.7}\right)$ with a 0.718 loading factor affecting quality management. This opinion is reinforced by the results of previous research conducted by Rahman (2016)[8] which states that the application of ISO 9001: 2008 QMS in the form of a management system approach has a significant effect on the performance of employees of PT PJB UP Muara Karang.

e. Quality Management $\left(\mathrm{X}_{2}\right)$ with indicators of Continuous Improvement $\left(\mathrm{X}_{2.10}\right)$ with a loading factor of 0.730 affecting quality management. This opinion is reinforced by the results of previous findings conducted by Rahman (2016)[8] which states that the application of ISO 9001: 2008 QMS in the form of continuous improvement has a positive and significant effect on the performance of employees of PT PJB UP Muara Karang. 
The results of the study concluded that Quality Management had a significant effect on Employee Performance of 2.897, meaning that the quality management (ISO 9001: 2008) applied in the library had a positive impact on the performance of Jember University Library employees. From the five indicators that influence quality management, indicators of All Employees Involvement $\left(\mathrm{X}_{2.3}\right)$ the biggest with a value of 0.875 loading factor. This can be concluded that employee involvement in organizational activities needs to be prioritized. This finding is in accordance with the research conducted by Rahman (2016)[8].

Table 1 shows the relationship between Quality Management $\left(\mathrm{X}_{2}\right)$ and Employee Performance $\left(\mathrm{Y}_{1}\right)$ is significant with T-Statistics 2.897 (> 1.96). The Original Sample value is positive at 0.404 which means that the direction of the relationship between Quality Management $\left(\mathrm{X}_{2}\right)$ and Employee Performance $\left(\mathrm{Y}_{1}\right)$ is positive. Thus the H2 hypothesis in this study which states that Quality Management $\left(\mathrm{X}_{2}\right)$ influences Employee Performance $\left(\mathrm{Y}_{1}\right)$ is accepted.

Table 1 shows the relationship between Information Technology $\left(\mathrm{X}_{1}\right)$ and Employee Performance $\left(\mathrm{Y}_{1}\right)$ is significant with T-Statistics 3.188 (> 1.96). The Original Sample value is positive at 0.471 which means that the direction of the relationship between Information Technology $\left(\mathrm{X}_{1}\right)$ and Employee Performance $\left(\mathrm{Y}_{1}\right)$ is positive. Thus the $\mathrm{H} 1$ hypothesis in this study which states that Information Technology $\left(\mathrm{X}_{1}\right)$ influences Employee Performance $\left(\mathrm{Y}_{1}\right)$ is accepted.

Table 1 shows the relationship between Information Technology $\left(\mathrm{X}_{1}\right)$ with Quality Management $\left(\mathrm{X}_{2}\right)$ is significant with T-Statistics 21.597 (> 1.96). The Original Sample value is positive at 0.844 which means that the direction of the relationship between Information Technology $\left(\mathrm{X}_{1}\right)$ and Quality Management $\left(\mathrm{X}_{2}\right)$ is positive. Thus the hypothesis H3 in this study which states that Information Technology $\left(\mathrm{X}_{1}\right)$ has an effect on Quality Management $\left(\mathrm{X}_{2}\right)$ is accepted.

Based on the Original Sample value, the highest value that influences Employee Performance $\left(\mathrm{Y}_{1}\right)$ is Information Technology $\left(\mathrm{X}_{1}\right)$ of 0.471 . Thus it can be concluded that Information Technology has a greater influence on Employee Performance compared to the influence between Quality Management on Employee Performance of 0.404.

\section{CONCLUSION}

By looking at the results of the research that has been done and by using the SMART-PLS analysis tool, it can be concluded that:

a.Information Technology on the Employee Performance of the University of Jember Library is influential so that the implementation of the technological developments used affects the performance of Jember University library employees

b.Information Technology on Quality Management is influential so that it can be concluded that the development of information technology in the Library influences quality management in the Jember University Library.

c.Quality Management of Employee Performance is influential so that it can be concluded that with good quality employee performance will be measurable

\section{References}

[1] Agustyantono, Galang., Fadah, Isti., Titisari, Purnamie. 2016. Pengaruh Kepemimpinan, Lingkugan Kerja dan Reward terhadap Kinerja Karyawan di Perum Pegadaian Cabang Besuki. Jurnal Busnis dan Manajemen, Vol. 10 No.1, Januari 2016. Sumber Daya Manusia dan Pemanfaatan Teknologi Informasi Konsekuensinya pada Kinerja Karyawan. STIEM, Makasar.

[2] Luburic, Radoica. 2015. Quality Management Principles and Benefits of their Implementation in Central Banks. Journal of Central Banking Theory and Practice, 2015, 3, pp. 91-121

[3] Prabowo, Sugeng Listyo. 2009. Implementasi Sistem Manajemen Mutu ISO 9001:2008 di Perguruan Tinggi. Malang: UIN Malang Press. Hlm. 19-20

[4] Sudaryanto. 2011. The Need for ICT Education for Managers or AgriBusinessmen for Increasing Farm Income: Study of Factor Influences on Komputer Adoption in East Java Farm Agribusiness. International Journal of Education and Development using Information and Communication Technology (IJEDICT), 2011, Vol.7, Issue 1, pp. 56-67

[5] Jumaili, Salman. 2005. Kepercayaan terhadap Teknologi Sistem Informasi Baru dalam Evaluasi Kinerja Individual. SNA VIII Solo, $15-16$ September 
[6] Nugroho, Novemy Triyandari. 2016. Pengaruh Penggunaan Teknologi Informasi terhadap Kinerja Karyawan (Studi Kasus Karyawan STMIK Duta Bangsa). Vol. 11, No.1 September 2016

[7] Tsani, Wulan Mutiara. 2017. Pengaruh Motivasi Kerja, Penggunaan Teknologi Informasi dan Kemampuan Berkomunikasi Interpersonal Terhadap Kinerja Karyawan (Studi di Bank Rakyat Indonesia (BRI) Syariah Cabang Surakarta). Surakarta: Fakultas Ekonomi dan Bisnis IAIN Surakarta.

[8] Rahman, Willian Tsania. 2016. Pengaruh Penerapan Sistem Manajemen Mutu ISO 9000:2008 terhadap Kinerja Karyawan (Studi kasus pada karyawan PT.PJB Unit Pembangkit Muara Karang).Jakarta: Jurusan Manajemen, Fakultas Ekonomi dan Bisnis, Universitas Islam Negeri Syarif Hidayatullah

[9] Suwanto, Sri Ati. 2006. Teknologi Informasi untuk perpustakaan dan pusat dokumentasi dan informasi. Jurnal FKP2T, Vol. 1 No.1. pp 22-26 ISSN 0854-9923

[10] Byars \& Rue, 2000. Human Resource Management: A Practical Approach. New York: Harcourt Brace

[11] Bernardin, H. John \& Joyce E. A. Russell, 1993, Human Resource Management. Singapore: McGraw Hill Inc

[12] Samuel, Hatane. 2011. Pengaruh Sistem Manajemen Mutu Iso Terhadap Kinerja Karyawan Melalui Budaya Kualitas Perusahaan (Studi Kasus PT. Otsuka Indonesia Malang) Jurnal Manajemen dan Kewirausahaan, Vol.13, No. 2, September 2011: 162-176

[13] Arisuniarti, Desak Made. 2016. Pengaruh Teknologi Informasi dan Sistem Informasi Manajemen Terpadu terhadap Kinerja Karyawan di Lingkungan Universitas Warmadewa. Public Inspiration (Jurnal Administrasi Publik), Desember 2016, Vol.1 No.1, 50-64

[14] Wai, Lai Siu Mane David Lai, et.al, 2011. Impact of information technology on quality management dimensions and its implications, European Business Review, Vol. 23 Iss 6 pp. $592-608$ 